DOI: https://doi.org/10.24144/2409-6857.2021.1(57).54-58

УДК 332.14

\title{
Петрецький I.I.
}

\section{НАПРЯМКИ РОЗВИТКУ СІЛЬСЬКИХ ТЕРИТОРІЙ УКРАЇНИ В УМОВАХ ДЕЦЕНТРАЛІЗАЦІї}

\begin{abstract}
У статті акцентовано на важливості сільських територій для розвитку держави в сучасних умовах. Окреслено основні причини сучасного стану та існуючих проблем сільських територій Украӥни. Виокремлено та охарактеризовано основні пріоритети сталого розвитку, які повинні бути враховані при формуванні иільових, міжгалузевих, секторальних програм розвитку, а також інвестиційних та бізнеспроектів сільських територій. Наведено ключові завдання щзодо розвитку сільських територіальних утворень у найближчій перспективі.
\end{abstract}

Ключові слова: сільська територія, державна регіональна політика, ефективний розвиток громад, пріоритети сталого розвитку сільських територій, завдання розвитку сільських територій.

Постановка проблеми. Забезпечення розвитку сільських територій $є$ актуальною соціально-економічною проблемою української держави. Це обумовлено тим, що на сільських територіях проживає більше третини населення країни та зосереджена значна частина природноресурсного потенціалу, який $\epsilon$ безальтернативною умовою розвитку вітчизняного агропромислового сектору. Останні роки динаміка кількості населення, яке проживає в сільській місцевості є негативною. Головними причинами цього $\epsilon$ низький рівень доходів, погіршення стану природніх ресурсів та екологічної ситуації, незадовільний розвиток соціальної інфраструктури сільських населених пунктів. Специфічні умови природного та соціального середовища сільських територій, виникнення яких супроводжується впливом політичних, соціальних, економічних та природніх факторів на сьогоднішній день характеризуються нестабільністю, зростаючою асиметрією та диспропорціями розвитку. Крім цього, існує ряд особливостей, які слід враховувати на сільських територіях, а саме: сезонний характер діяльності, залежність процесу виробництва від впливу об'єктивних біологічних.

Аналіз останніх досліджень i публікацій. Проблематика розвитку сільських територій досліджується в працях багатьох вітчизняних учених, зокрема таких як: I. Гончарук [1], I. Томашук [1], С. Харчук [11], А. Котляр [3], О. Грубляк [3], В. Підвисоцький [8], Р. Ткачук [8] та ін. Але, незважаючи на потужний доробок вітчизняної економічної науки щодо забезпечення ефективного соціально-економічно-

(ОПетрецький I.I., аспірант кафедри економіки i підприємництва, ДВНЗ «Ужгородський національний університет» го розвитку сільських територій, існує потреба поглибленого дослідження та розкриття змісту основних напрямів розвитку сільських територій в умовах адміністративно-територіальної реформи та децентралізації владних повноважень, а також розкриття аспектів управління розвитком сільських територій.

Формулювання цілей статті. Головним завданням даного дослідження $€$ висвітлення основних напрямків розвитку сільських територій в умовах децентралізації.

Виклад основного матеріалу дослідження. На сільських територіях високими темпами і у великих масштабах відбувається знелюднення, що за теорією просторової економіки неминуче призведе до зниження капіталізації активів, як виробничого, так і природного характеру та створює підгрунтя для масової спекуляції землею. На сьогодні в Україні спостерігається негативна демографічна ситуація на селі. За даними Державної служби статистики України за 20102020 роки чисельність сільського населення скоротилася на 16\% [6]. Природне зменшення сільського населення в Україні обумовлене майже двократним перевищенням смертності над народжуваністю. Гостроти демографічним проблемам надають міграційні процеси, які останнім часом в значній мірі активізувались.

Основними причинами сучасного стану сільських територій $€$ : наявні проблеми ігнорування фундаментальних основ сільського розвитку; політика держави, що не була змодельована та не адаптована до стану національних інститутів; де-юре відсутня, а дефакто агрохолдингова модель сільського розвитку; нерівномірний розподіл земельних, водних, лісових та інших ресурсів, розміщених на сільських територіях; корумпованість регіональних та місцевих влад; слабка участь влади у вдосконаленні та контролі земельного 
законодавства; відсутність ефективної державної політики розвитку села; відсутність доступних інвестиційних засобів у сільськогосподарських виробників; занепад сучасної інженерної та соціальної інфраструктури, відсутність у громадян матеріальних можливостей побудови свого житла на селі, технічне відставання сільських територій [2].

Ключовою проблемою вітчизняних аграрних реформ, включаючи i реформу форм господарювання, $\epsilon$ невизначеність виконавчих інститутів влади 3 моделлю аграрного устрою. Більше того, в умовах здійснення адміністративно-територіальної реформи та 3 метою ефективного протікання процесів децентралізації влади, громади сільських територій повинні розробити програми свого подальшого розвитку, зважаючи на власні потенційні можливості та проблемні аспекти. Це означає, що кожна новостворена територіальна громада повинна розуміти, що від того, як вона забезпечить своє позиціонування, як буде використовувати наявні власні ресурси буде залежати ії подальший розвиток.

3 метою ефективної реалізації державної регіональної політики було прийнято Закон України «Про засади державної регіональної політики» [9], який законодавчо визначає правові, економічні, організаційні, соціальні, гуманітарні засади регіонального розвитку. Законом передбачено:

- зменшення територіальної диференціації за індексом регіонального людського розвитку;

- розробку та реалізацію проєктів підвищення конкурентоспроможності сільських територій;

- покращення матеріальної, інформаційної, кадрової складових розвитку регіонів;

- сприяння здійсненню повноважень органами місцевого самоврядування;

активізацію та підтримку місцевих ініціатив щодо ефективного використання внутрішнього потенціалу регіону для створення повноцінного життєвого середовища, підвищення якості життя людей.

Варто відзначити, що станом на 6 січня 2021 p. в Україні було затверджено 1298 бюджетів місцевих громад, що становить 81 \% від їхньої загальної кількості (1597) [6]. Повноцінне функціонування закладів бюджетної сфери задля можливості надання ними послуг вимагає прискорення процесів затвердження місцевих процесів.

Як вважає В. Підвисоцький, при формуванні цільових, міжгалузевих, секторальних програм розвитку, інвестиційних та бізнес-проектів необхідно здійснити ряд підготовчих заходів: провести аналіз наявних ресурсів на сільській території, a також поточного стану їх використання (мінеральних, земельних, виробничих, трудових); дослідити маркетингове середовище щодо конкурентоспроможності товарів, послуг, інфраструктури, організаційногоуправлінського забезпечення; визначити

потенційні та реальні переваги території; визначити напрями розвитку виробництва сільської території з урахуванням географічного розташування території, внутрішніх та зовнішніх ринків збуту, стану природних та трудових ресурсів; проаналізувати поточний та перспективний бюджети сільської території [8].

До головних складових ефективного розвитку сільських територій на їх об'єднаних громад відносять:

забезпечення

адекватного, висококваліфікованого персоналу, у тому числі шляхом навчання молоді та керівництва ОТГ за рахунок бюджету, суб'єктів господарювання та інших джерел, для отримання кращого досвіду управління та маркетингу i досягнення синергетичного ефекту розвитку;

- організація високотехнологічних виробництв шляхом залучення висококваліфікованих спеціалістів 3 можливістю використання основних засобів, які не використовуються на території ОТГ;

підготовка в межах шкільних та позашкільних програм працівників робочих професій, найбільш поширених на території за рахунок коштів підприємств та організацій, розміщених в ОТГ на засадах домовленості; пожвавити місцеву економіку, головним чином за рахунок виробництв, які працюють 3 місцевими ресурсами; розвиток туризму, рекреації та здоровлення людей за допомогою місцевих природних ресурсів [1].

Як вважає Б. Панасюк, саме розвиток сільського господарства, відновлення його виробничих потужностей, кооперація сільського господарства та торгівлі, переробної промисловості надасть можливість відродити сільські території [7, с.213].

При цьому слід також зазначити, що село може використовувати й інші ресурси, а не лише здійснювати виробництво сільськогосподарської продукції. До таких видів діяльності можна віднести зелений туризм, невеликі локальні промисли, започаткування та підтримка культурно-історичних туристичних маршрутів, виробництво органічної продукції та багато іншого.

Отже, для того щоб відбулися зазначені зміни, 
на сільській території необхідно забезпечити передусім ефективне самоврядування, націлене на отримання позитивних результатів, здійснити розроблення перспективного плану дій та неухильно його виконувати та контролювати, розробити промоцію своєї території, сприяти виникненню якомога більшої чисельності підприємців, які в подальшому забезпечать фінансову незалежність територіальної громади та іiї соціальних проектів.

Також С. Харчук наголошує на тому, що сільські території мають інтегруватися в урбанізовану систему, якщо хочуть залучити до себе зовнішні інвестиційні ресурси. При цьому повинен працювати підхід знизу вгору, коли люди самі розробляють свої програми розвитку, їх реалізують, а фінансування здійснюється на основі фандрайзингу [11, с. 21].

Стратегічною метою сталого розвитку

сільських територій визначено забезпечення збалансованого економічного, демографічного, соціального та екологічного розвитку сільських територій на основі підвищення конкурентоспроможності й дохідності сільськогосподарського виробництва, диверсифікації господарської діяльності та розширення несільськогосподарського підприємництва на селі, охорони й раціонального використання природних, трудових і виробничих ресурсів сільських територій, досягнення соціальних стандартів і нормативів проживання для сільського населення [4].

Грунтуючись на ідеї селозберігаючої моделі аграрного устрою та в розвиток Концепції розвитку сільських територій в НАAН обгрунтовано стратегічні пріоритети сталого розвитку сільських територій на період до 2025 року (табл. 1).

Таблиця 1

Науково-обгрунтовані пріоритети сталого розвитку сільських територій до 2025 року

\begin{tabular}{|c|c|}
\hline $\begin{array}{c}\text { Соціально-демографічний } \\
\text { вектор }\end{array}$ & $\begin{array}{l}\text { Покращення умов життя сільського населення. } \\
\text { Соціальний захист селян. } \\
\text { Доступність освіти та якісної медичної допомоги. } \\
\text { Формування розвиненої транспортної інфраструктури. } \\
\text { Зайнятість сільського населення. }\end{array}$ \\
\hline Економічний вектор & $\begin{array}{l}\text { Формування сільськогосподарської обслуговуючої кооперації. } \\
\text { Розвиток сільського туризму. } \\
\text { Розвиток підприємництва, малих форм господарювання. }\end{array}$ \\
\hline Екологічний вектор & $\begin{array}{l}\text { Дбайливе ставлення до природних ресурсів, раціональне їх } \\
\text { використання. } \\
\text { Досягнення екологічної та техногенної безпеки сільських } \\
\text { територій. }\end{array}$ \\
\hline $\begin{array}{c}\text { Інституційне та інноваційно- } \\
\text { інвестиційне забезпечення }\end{array}$ & $\begin{array}{l}\text { Сприяння залученню інвестицій. } \\
\text { Формування інноваційного забезпечення. } \\
\text { Належне матеріально-технічне та грошово-кредитне } \\
\text { забезпечення. } \\
\text { Покращення управлінських процесів у сільських територіях. } \\
\text { Формування належного рівня сучасного інформаційного } \\
\text { забезпечення. }\end{array}$ \\
\hline
\end{tabular}

Автори I.О. Іртищева, Т.В. Стройко та М.I. Стегней, проводячи моніторинг сталого розвитку сільських територій, зазначають, що для досягнення належного рівня соціальноекономічного розвитку сільських територій та створення умов для ефективного функціонування агропромислового виробництва необхідним $\epsilon$ прийняття рішення щодо посилення державної підтримки [10, с. 109].

Натомість, А.Б. Котляр та О.М. Грубляк, досліджуючи джерела фінансування розвитку сільських територій, обгрунтовують необхідність розвитку кооперації [3, с. 63-64]. Таким чином, сільські жителі зможуть самостійно ефективно управляти належними їм територіями та об'єднуватися в кооперативи. Як показує сучасна світова практика, саме кооперативна форма організації на селі дає позитивні результати. Об'єднання в кооперативи дозволяє селянину отримати роботу, задовольнити потребу в технічних та матеріальних засобах для ведення сільськогосподарського виробництва. I що не менш важливо - вирішити найголовнішу проблему на селі - збут вирощеної сільськогосподарської продукції. Кооперативна форма на селі дає можливість сільському жителю відчути себе справжнім господарем. Таким чином, стане можливим відродження 
інфраструктури та вирішення нагальних потреб селянина. На відміну від холдингових компаній, які домінують у використанні земель сільськогосподарського призначення, сільськогосподарські обслуговуючі кооперативи будуть надавати послуги малозахищеним верствам сільського населення. Роль кооперативів стає ще більш значущою за умов децентралізації на селі. Громади самостійно зможуть вирішувати нагальні потреби сільських жителів, а інструментом цього будуть слугувати створені ними кооперативи.

Отже, основними завданнями щодо розвитку сільських територіальних утворень у найближчій перспективі є:

1. Неухильне підвищення якості життя сільського населення, зменшення рівня диференціації їx розвитку та забезпечення розширеного інноваційного відтворення ресурсного потенціалу територіальногосподарського комплексу на основі оптимального співвідношення інтересів економічного, соціального та екологічного компонентів території.

2. Забезпечення можливостей реалізації розширеного аграрного виробництва, яке забезпечує випуск необхідної кількості товарів із найменшими витратами за ефективного використання чинників виробництва в необхідні терміни.

3. Формування й реалізація концепції «органічного землеробства», що передбачає ефективну систему виробничого та екологічного менеджменту, яка заохочує і покращує природне розмаїття території.

4. Орієнтація науково-технічного прогресу на розвиток особистості й на інституційні позитивні зміни, які повинні бути узгоджені між собою і сприяти зміцненню наявного й майбутнього потенціалу для задоволення потреб сільського населення.

5. Акцент на виробництві екологічно чистої сільськогосподарської продукції та впровадженні інновацій.

6. Здійснення регіональної політики для задоволення загальнонаціональних та регіональних інтересів.

7. Формування безпечного та мирного суспільства із спільними цінностями та належними інституціями.

Висновки i перспективи подальших досліджень. Реформа децентралізації влади в Україні, метою якої $є$ підвищення якості життя населення, забезпечення відтворення природних систем на базі ефективного комплексного економічного і соціального розвитку регіону, відбувається досить повільними темпами. Одним iз пріоритетних загальнодержавних завдань $\epsilon$ запровадження суспільної політики задля вирішення питань розвитку сільських територій. Ефективна державна політика $\epsilon$ запорукою соціально-економічного розвитку сільських територій та важливим інструментом пришвидшення формування сільських об’єднаних територіальних громад.

\section{ПЕРЕЛІК ВИКОРИСТАНИХ ДЖЕРЕЛ}

1. Гончарук І.В., Томашук І.В. Державне регулювання розвитку ресурсного потенціалу сільських територій: загальні аспекти. Економіка. Фінанси. Менеджмент: актуальні питання науки і практики. 2018. № 4 (32). С.19-30. 2. Концепція розвитку сільських територій: розпорядження Кабінету Міністрів України від 23 вересня 2015 р. № 995-p. URL: https://zakon.rada.gov.ua/laws/show/995-2015-\%D1\%80. (дата звернення: 21.03.2019).

3. Котляр А. Б., Грубляк О. М. Сутність фінансових ризиків підприємства та методичні підходи до їх оцінки у процесі прийняття фінансово-інвестиційний рішень. Кримський економічний вісник. Херсон, 2013. № 1. С. 6365.

4. Наукові основи і стратегічні пріоритети сталого розвитку сільських територій України / Гадзало Я.М., Жук В.М., Могилова М.М. та ін.; за ред. Я.М. Гадзала. К.: ННЦ «ІАЕ», 2019. 40 с.

5. Національна економічна стратегія-2030 від 03 березня 2021 р. № 179. URL: https://nes2030.org.ua 6.Офіційний сайт Державної служби статистики URL: http://ukrstat.gov.ua/operativ/operativ2008/vvp/vvp_ric/vtr_u.htm (дата звернення 11.03.22020p.)

7. Панасюк Б.Я. Шлях до відродження села. Соціально-економічні проблеми розвитку українського села i сільських територій: матеріали сьомих річних зборів Всеукраїнського конгресу вчених економістів-аграрників. K., 2005. C. 211-217.

8. Підвисоцький В., Ткачук Р. Формування та впровадження програм підвищення конкурентоспроможності територій: метод. Матеріали. К.: Леста, 2010. 64 с.

9. Про засади державної регіональної політики: Закон України від5.02.2015p.№ 156-VIII. URL: interfax.com.ua/news/political/248850.html (дата звернення 06.03.2020p.)

10. Стройко Т. В., Іртищева I. О., Стегней М. І. Моніторинг екологічно сталого розвитку сільських територій в умовах глобальних викликів Економіка природокористування і охорони довкілля. Київ: Державна установа «Інститут економіки природокористування та сталого розвитку Національної академії наук». 2014. С. $109-111$. 
11. Харчук С.А. Соціально-економічний розвиток сільських територій: проблеми та шляхи вирішення. Інвестиції: практика та досвід. 2015. № 12. С. 20-23.

\section{REFERENCES}

1. Honcharuk, I.V., \& Tomashuk, I.V. (2018). Derzhavne rehulyuvannya rozvytku resursnoho potentsialu silskykh terytoriy: zahalni aspekty [State regulation of resource potential development in rural areas: general aspects]. Ekonomika. Finansy. Menedzhment: aktualni pytannya nauky i praktyky - Economy. Finances. Management: current issues of science and practice, 4 (32), 19-30 [in Ukrainian].

2. Kontseptsiya rozvytku silskykh terytoriy: rozporyadzhennya Kabinetu Ministriv Ukrayiny vid 23 veresnya 2015 r. № 995-r [The concept of rural development: the order of the Cabinet of Ministers of Ukraine from September 23, 2015 № 995-r]. (2015). Retrieved from: https://zakon.rada.gov.ua/laws/show/995-2015-\%D1\%80 [in Ukrainian].

3. Kotlyar, A.B., \& Hrublyak, O.M. (2013). Sutnist' finansovykh ryzykiv pidpryyemstva ta metodychni pidkhody do yikh otsinky u protsesi pryynyattya finansovo-investytsiynyy rishen' [The essence of financial risks of the enterprise and methodological approaches to their assessment in the process of making financial and investment decisions]. Krymskyy ekonomichnyy visnyk - Crimean Economic Bulletin, 1, 63-65 [in Ukrainian].

4. Hadzalo, Ya.M (Eds.) (2019) Naukovi osnovy i stratehichni priorytety staloho rozvytku silskykh terytoriy Ukrayiny [Scientific bases and strategic priorities of sustainable development of rural areas of Ukraine]. K.: NNTS «IAE» [in Ukrainian].

5. Natsionalna ekonomichna stratehiya-2030 vid 03 bereznya 2021 r. № 179. [National Economic Strategy-2030 from March 3, 2021 № 179]. (2021). Retrieved from: https://nes2030.org.ua [in Ukrainian].

6. Ofitsiynyy sayt Derzhavnoyi sluzhby statystyky Ukrayiny [Official site of the State Statistics Service of Ukraine]. (n.d.). Retrieved from: http://ukrstat.gov.ua/operativ/operativ2008/vvp/vvp_ric/vtr_u.htm [in Ukrainian].

7. Panasyuk, B.Ya. (2005). Shlyakh do vidrodzhennya sela [The way to the revival of the village]. Proceedings from: Vseukrayinskyyoho konhres vchenykh ekonomistiv-ahrarnykiv «Sotsialno-ekonomichni problemy rozvytku ukrayinskoho sela i silskykh terytoriy» - the All-Ukrainian Congress of Agrarian Economists «Socio-economic problems of development of the Ukrainian village and rural territories» (pp. 211-217) [in Ukrainian].

8. Pidvysotskyy, V., \& Tkachuk, R. (2010). Formuvannya ta vprovadzhennya prohram pidvyshchennya konkurentospromozhnosti terytoriy: metod. materialy. [Formation and implementation of programs to increase the competitiveness of territories: a method. materials]. K.: Lesta [in Ukrainian].

9. Pro zasady derzhavnoyi rehionalnoyi polityky: Zakon Ukrayiny vid 05.02.2015 r. № 156-VIII [On the principles of state regional policy: Law of Ukraine from February 5, 2015 №156-VIII]. (2015). Retrieved from: interfax.com.ua/news/political/248850.html [in Ukrainian].

10. Stroyko, T.V., \& Irtyshcheva, I.O., \& Stehney, M.I. (2014). Monitorynh ekolohichno staloho rozvytku silskykh terytoriy $\mathrm{v}$ umovakh hlobalnykh vyklykiv [Monitoring of ecologically sustainable development of rural areas in the context of global challenges]. Ekonomika pryrodokorystuvannya i okhorony dovkillya - Economics of nature management and environmental protection, 109-111 [in Ukrainian].

11. Kharchuk, S.A. (2015). Sotsialno-ekonomichnyy rozvytok silskykh terytoriy: problemy ta shlyakhy vyrishennya [Socio-economic development of rural areas: problems and solutions]. Investytsiyi: praktyka ta dosvid - Investments: practice and experience, 12, 20-23 [in Ukrainian].

Отримано 10.03.2021 